\title{
Health aspects of geraniol as a main bioactive compound of Rosa damascena Mill: a systematic review
}

$$
\text { Zahra Hadian }^{1 *} \text {, Majedeh Maleki }{ }^{1}, \text { Ehsan Feizollahi }^{2} \text {, Sepideh Alibeyk }{ }^{3} \text {, Maryam Saryazdi }{ }^{3}
$$

${ }^{1}$ Department of Food Science and Technology, National Nutrition Science and Food Science Technology Research Institute, Shahid Beheshti University of Medical Sciences, Tehran, Iran

${ }^{2}$ Department of Agricultural, Food \& Nutritional Science, University of Alberta, Edmonton, Canada

${ }^{3}$ Department of Library, National Nutrition Science and Food Science Technology Research Institute, Shahid Beheshti University of Medical Sciences, Tehran, Iran

\section{Type of article: Systematic Review}

\begin{abstract}
Background: Geraniol (GE), as secondary metabolites of plant and natural bioactive essential oils is one of the major compounds of Rosa damascena Mill and widely used as fragrance/flavor in the food industry. Rosa damascena Mill and geraniol have numerous health benefits for human consumption. Currently, there is no single article that extensively covers the complete range of beneficial effects of GE that could improve knowledge in this category.

Objective: The purpose of this study was to provide a comprehensive review of all published specific articles about beneficial properties of GE, as a monoterpene component of medicinal plants.

Methods: Data were selected from Scopus, Clarivate Web Of Science ${ }^{\mathrm{TM}}$, Embase, ScienceDirect and PubMed databases from 1940-2019 by identifying keywords and creating complex searches.

Results: Based on the search results, GE identified as a natural compound having insecticidal and repellent activities. GE introduces a new class of cancer chemopreventive agents due to its citronellol and trans-geraniol. Other functional properties such as antibacterial, antifungal, antioxidant and anti-inflammatory of GE have also been found.

Conclusion: Overall, this approach has been a systematic literature review to provide an effective strategy for rapidly evaluating research results. This study suggests that the GE and Rosa damascena Mill have multiple health benefits and they are recommended for their therapeutic effects.

Keywords: Geraniol; Medicinal plant; Bioactivity; Rosa damascene
\end{abstract}

\begin{abstract}
Abbreviations / Acronyms:
AIDS: Acquired Immunodeficiency Syndrome; GE: Geraniol; PRISMA: Preferred Reporting Items for Systematic Reviews and Meta-Analyses; TD: Thymus Daenensis.

Note:

This study has followed the Preferred Reporting Items for Systematic Reviews and Meta-Analyses: The PRISMA Statement (http://www.prisma-statement.org). PRISMA is an evidence-based minimum set of items for reporting in systematic reviews and meta-analyses. PRISMA focuses on the reporting of reviews evaluating randomized trials, but can also be used as a basis for reporting systematic reviews of other types of research, particularly evaluations of interventions.
\end{abstract}

\section{Introduction}

Medicinal plants have always been regarded as one of the best therapies for human health problems. Many traditional medicinal plants have been examined for their antitumor potential in cell culture or in animal models (1,

\section{Corresponding author:}

Assistant Professor Dr. Zahra Hadian. National Nutrition and Food Technology Research Institute, Shahid Beheshti University of Medical Sciences. Tel: +98.2122376467, Fax: +98.2122376467, E-mail: z_hadian@sbmu.ac.ir Received: September 20, 2019, Accepted: February 28, 2020, Published: September 2020

iThenticate screening: February 26, 2020, English editing: July 19, 2020, Quality control: August 12, 2020

(C) 2020 The Authors. This is an open access article under the terms of the Creative Commons Attribution-NonCommercialNoDerivs License, which permits use and distribution in any medium, provided the original work is properly cited, the use is non-commercial and no modifications or adaptations are made. 
2). They indicate anticancer effects via inhibiting cancer-activating enzymes, stimulating the production of protective enzymes, encouraging DNA repair, promoting antioxidant action and enhancing body immunity (1). Bioactive molecules as secondary metabolites of plants show defense mechanisms against herbivores, predation, microbial invasion, fungal attack, viral infection and microbial invasion. These molecules can be obtained from essential oils. Natural and bioactive compounds possess properties including disease preventing, health promoting or medicinal properties. There are three major groups of secondary metabolites that include: nitrogen-containing substances, terpene and phenolic (3-7).

The terpenoids represent one of the largest groups of secondary metabolites which are synthesized via the fivecarbon building block isoprene $(8,9)$. The main groups are monoterpenes, sesquiterpenes, diterpenes, triterpenes, steroids and tetraterpenes with 10,15, 20,30, 27 and 40 carbon atoms, respectively. Terpenes may have complex structures because of various chemical groups and secondary ring formations. Mono- and sesquiterpenes are often volatile and can be distilled as essential oils, for example, menthol, thymol and thujone. They occur in several families including Asteraceae, Lamiaceae, Lauraceae, Rutaceae and Zingiberaceae. Terpenes often have antimicrobial and cytotoxic activities against a range of organisms and may be used to treat bacterial and parasitic infections as well as respiratory disorders $(10,11)$. Citronellol, geraniol (GE), nonadecane and phenylethyl alcohol are the most important compounds in the essential oil of Rosa Damascene (12-18). Plant secondary metabolites have a wide range of biological activities, and thus have been used in traditional medicine. Synthetic pharmaceuticals are made from single chemicals whilst phytomedicines commonly wield their favorable effects via the synergistic action of several phytochemical compounds acting at single or multiple target sites linked with a physiological process (1921). The aim of the present review is to give a useful summary of the published data on the biological properties of GE.

\section{Material and Methods}

\subsection{Research design and search strategy}

In this study we chose to search through the range of resources available from digital / electronic libraries in all English-language publications aiming to raise public health awareness (Figure 1). Topics relevant to this review were assessed. The results of this study were investigated based on articles published in Iranian and international journals. In this study, all published articles from 1940 to the end of 2020 were chosen by searching the databases of Embase $(n=236)$, Scopus $(n=318)$, ScienceDirect $(n=43)$, Clarivate Web Of Science ${ }^{\mathrm{TM}}(\mathrm{n}=308)$ and PubMed $(\mathrm{n}=163)$. Articles were searched using English keywords and prefixes such as geraniol OR health OR bioact OR anti OR benef OR treat OR therap OR pharma OR fung OR microb OR propert individually and combined or articles in the reference list.

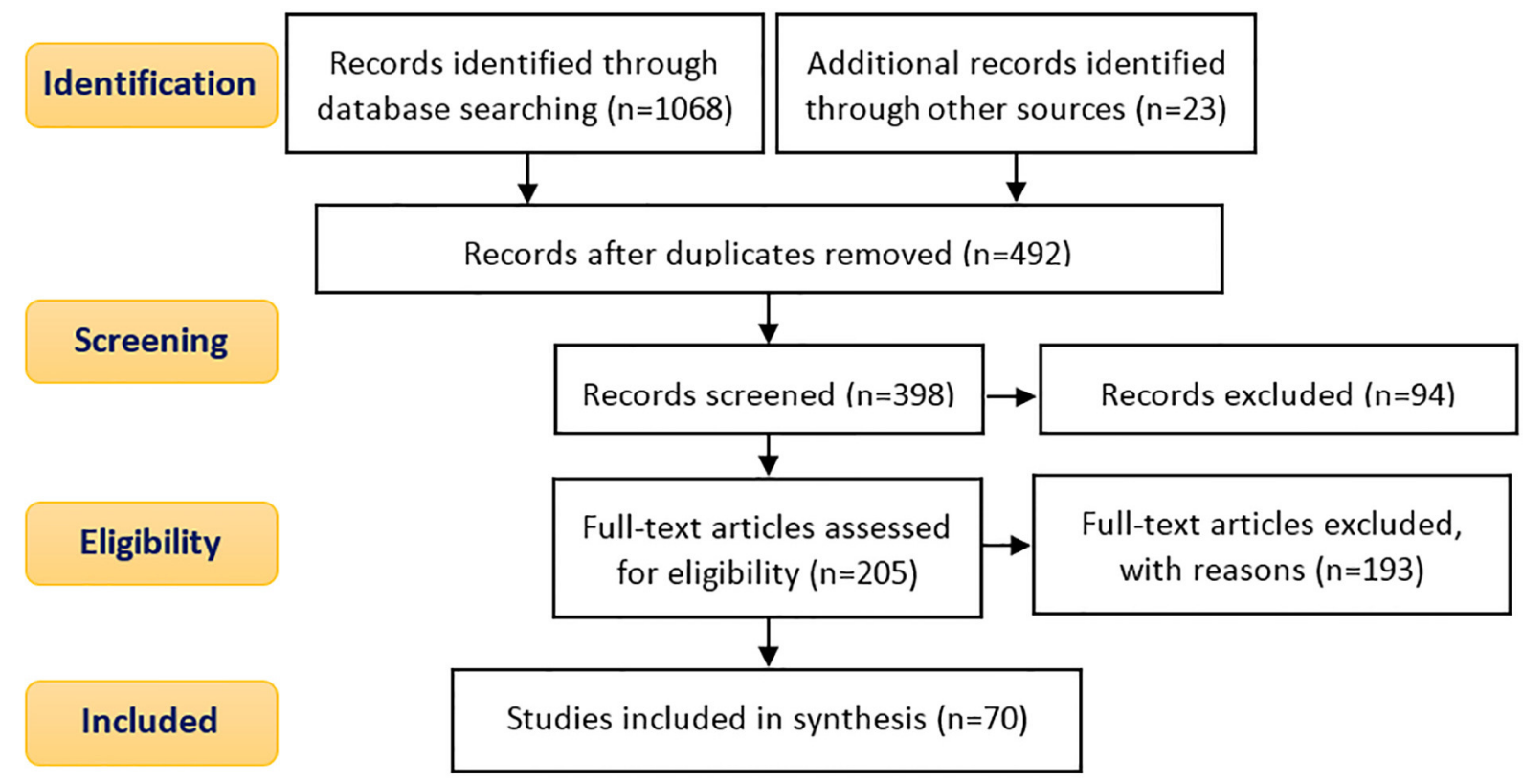

Figure 1. Flowchart of information in different phases of the systematic review 


\subsection{Inclusion and exclusion criteria}

All evidence into a qualitative form based on inclusion criteria such as all experimental and observational research, the time period (between 1976 and 2020), English language, with setting the health aspect of GE with toxicological and pharmacological effects were carried out. Similarly, other criteria were considered as exceptions.

\section{Results and Discussion}

\subsection{Rosa Damascena Mill}

The production of favorable odors using flowers and leaves has a long history (Figure 2). Essential oils are the most useful and valuable natural perfume oils extracted from rose plants. Although only approximately $20 \%$ of the wild species are in the group of 'fragrant' compounds, over 400 volatile compounds have been found in rose oil (22). In the case of essential oils, there is a strong relation between their content and composition with species and cultivars. Currently, rose oils (attar of roses) and a semisolid extract (rose concrete) are produced using R. Damascena (Bulgarian rose oil) and R. Centifolia (Moroccan rose oil) which are commercially the most important species; Turkey, Iran, Bulgaria and Russia are the major regions for the production (23). In Iran, Rosa damascenes Mill, which is known as Damask Rose (22), is named Gole Mohammadi (23). It is one of the main species of the Rosaceae family which is widely used as an ornamental plant and has been named as the king of flowers (24). To date, more than 2000 rose species and over 18000 cultivars have been recognized (25). Rosa damascene Mill (R. damascene) is an aromatic plant with light pink flowers that blossom in spring (26). Iran is one of the main origins of R. damascene (27) and its cultivation and consumption have a long history in this country $(3,28,29)$. Until the 16 th century, the main producer and exporter of rose oil throughout the world was Iran $(30,31)$. The compositions of $R$. damascena essential oil growing in Iran and analyzed by GC/MS are indicated in Table 1. It's widely used for the purpose of decoration and perfumery (32). In addition to this property, it is greatly cultivated for its medicinal properties. Recent studies have indicated that anti-HIV, antioxidant and anti-bacterial activity essential oils can be extracted from $R$. Damascena (33-39). The rose oil is recognized as one of the most expensive essential oils in the world due to the low amount of Rosa genus oil and the lack of natural and synthetic substitutes (36-39). This plant has a lot of advantages such as being a cardiotonic agent, and having anti-inflammatory, astringent cooling and soothing effects (40). Recently, aromatic plants rich in essential oils have become of interest in food products due to their antibacterial and antioxidant properties (41). Based on the chromatographic results, citronellol (14.5-47.5\%), GE (5.5-18\%), heneicosane (7-14\%) and nonadecane (10.5-40.5\%) were major components of $R$. damascena oil (Kashan, Iran) (23). In a number of studies, citronellol, GE and nerol were found to be three main components of rose oil, which possessed strong antimicrobial activity $(42,43)$. The essential oils of Rosa damascene are found to be the most suitable precursors for medicinal, and perfumery applications as well as cosmetic preparation $(34,36)$.

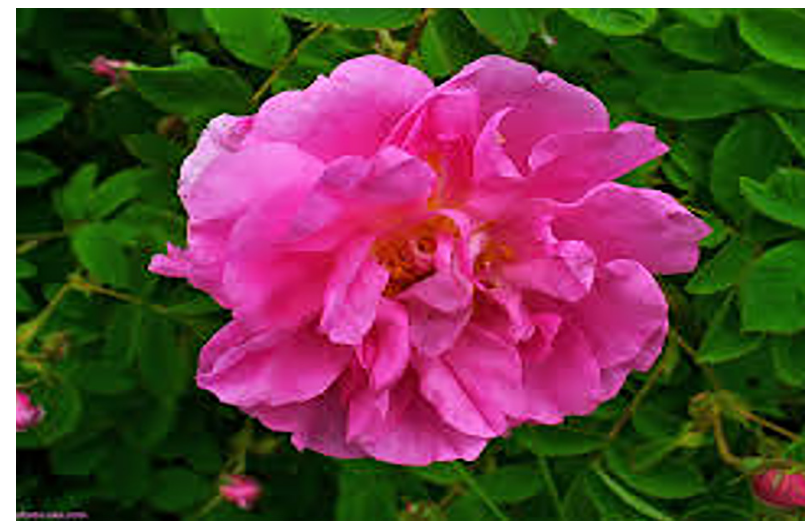

Figure 2. The plant of R. damascene 
Table 1. Chemical constituents (\%) of the essential oil of Rose damascena in Kashan (Barij Essence Pharmaceutical Company)

\begin{tabular}{|c|c|c|c|c|c|c|c|c|c|}
\hline No. & Compound & RI & $\begin{array}{l}\text { RT } \\
\text { Rose } \\
\text { EO }\end{array}$ & $\begin{array}{l}\text { Concentration } \\
(\%)\end{array}$ & No. & Compound & RI & $\begin{array}{l}\text { RT } \\
\text { Rose } \\
\text { EO }\end{array}$ & $\begin{array}{l}\text { Concentration } \\
(\%)\end{array}$ \\
\hline 1 & $\alpha$-Pinene & 933.7 & 5.92 & 0.3931 & 35 & $\alpha$-humulene & 1456 & 19.45 & 0.3299 \\
\hline 2 & $\beta$-Pinene & 978.1 & 6.98 & 0.0443 & 36 & $\begin{array}{l}\text { Geranyl } \\
\text { propanoate }\end{array}$ & 1474 & 19.9 & 0.0695 \\
\hline 3 & $\beta$-Myrcene & 989.9 & 7.08 & 0.1447 & 37 & $\begin{array}{l}\text { Germacrene } \\
\text { D }\end{array}$ & 1484 & 20.07 & 0.5418 \\
\hline 4 & p-Cymene & 1024 & 8.19 & 0.0793 & 38 & $\beta$-Selinene & 1489 & 20.34 & 0.2318 \\
\hline 5 & Limonene & 1029 & 8.39 & 0.0458 & 39 & pentadecane & 1498 & 20.45 & 0.0987 \\
\hline 6 & 1,8-Cineole & 1032 & 8.52 & 0.0532 & 40 & $\alpha$-Muurolene & 1501 & 20.49 & 0.2484 \\
\hline 7 & Linalool & 1102 & 10.22 & 3.7261 & 41 & $\delta$-Guaiene & 1508 & 20.87 & 0.6127 \\
\hline 8 & Nonanal & 1104 & 10.37 & 0.7168 & 42 & $\Delta$-Cadinene & 1526 & 21.02 & 0.0454 \\
\hline 9 & cis-Rose oxide & 1112 & 10.83 & 0.2615 & 43 & $\begin{array}{l}\text { Citronellyl } \\
\text { butanoate }\end{array}$ & 1527 & 21.09 & 0.078 \\
\hline 10 & Benzeneethanol & 1119 & 11.18 & 1.2875 & 44 & $\begin{array}{l}\text { Geranyl } \\
\text { butanoate }\end{array}$ & 1561 & 21.65 & 0.2802 \\
\hline 11 & trans-Rose oxide & 1129 & 11.55 & 0.0773 & 45 & E-Nerolidol & 1565 & 21.88 & 0.1115 \\
\hline 12 & menthone & 1156 & 11.86 & 0.2338 & 46 & $\begin{array}{l}\text { 2-Phenyl } \\
\text { ethyl tiglate }\end{array}$ & 1588 & 22.8 & 0.4795 \\
\hline 13 & Isomenthone & 1167 & 12.15 & 1.0996 & 47 & hexadecane & 1597 & 23.06 & 0.0471 \\
\hline 14 & 4-Terpineol & 1181 & 12.56 & 0.4124 & 48 & $\begin{array}{l}\text { 10-epi- } \gamma \text { - } \\
\text { eudesmol }\end{array}$ & 1625 & 23.69 & 0.2771 \\
\hline 15 & $\alpha$-Terpineol & 1196 & 13.05 & 0.6509 & 49 & $\gamma$-Eudesmol & 1636 & $\operatorname{tr}$ & $\operatorname{tr}$ \\
\hline 16 & $\beta$-Citronellol & 1240 & 14.01 & 50.6268 & 50 & Cubenol & 1647 & 23.82 & 0.0114 \\
\hline 17 & Neral & 1246 & 14.18 & 0.3335 & 51 & $\beta$-Eudesmol & 1656 & 23.88 & 0.0631 \\
\hline 18 & Carvone & 1251 & 14.27 & 0.0731 & 52 & $\alpha$-Cadinol & 1659 & 23.99 & 0.1294 \\
\hline 19 & Geraniol & 1263 & 14.59 & 11.2085 & 53 & $\begin{array}{l}\text { E-Citronellyl } \\
\text { tiglate }\end{array}$ & 1666 & 24.08 & 0.1582 \\
\hline 20 & Geranial & 1275 & 14.76 & 0.54 & 54 & $\begin{array}{l}\text { Heptadec-8- } \\
\text { ene }\end{array}$ & 1675 & 24.16 & 0.0604 \\
\hline 21 & $\begin{array}{l}\text { Citronellyl } \\
\text { formate }\end{array}$ & 1278 & 14.76 & 2.93 & 55 & Heptadecane & 1698 & 24.42 & 1.0204 \\
\hline 22 & Neryl formate & 1283 & 14.89 & 0.1859 & 56 & $\begin{array}{l}\text { Geranyl } \\
\text { tiglate }\end{array}$ & 1702 & 24.49 & 0.0726 \\
\hline 23 & E-Anethole & 1290 & 14.99 & 0.1308 & 57 & $\begin{array}{l}2 \mathrm{z}, 6 \mathrm{E}- \\
\text { Farnesol }\end{array}$ & 1725 & 24.89 & 0.2815 \\
\hline 24 & Geranyl formate & 1303 & 15.45 & 0.6207 & 58 & $\begin{array}{l}\text { Benzyl } \\
\text { Benzoate }\end{array}$ & 1768 & 26.5 & 0.1373 \\
\hline 25 & Methyl geranate & 1325 & 16.05 & 0.1 & 59 & Octadecane & 1797 & 27.14 & 0.0936 \\
\hline 26 & $\begin{array}{l}\text { Citronellyl } \\
\text { acetate }\end{array}$ & 1354 & 16.53 & 0.0749 & 60 & $\begin{array}{l}1- \\
\text { Nonadecene }\end{array}$ & 1872 & 28.06 & 1.6251 \\
\hline 27 & Eugenol & 1361 & 16.63 & 0.3741 & 61 & Nonadecane & 1900 & 28.56 & 7.4944 \\
\hline 28 & $\alpha$-copaene & 1378 & 17.39 & 0.9716 & 62 & 1-Eicosene & 1970 & 29.95 & 0.0663 \\
\hline 29 & Geranyl acetate & 1384 & 17.44 & 0.3463 & 63 & Eicosane & 1996 & 30.39 & 0.8736 \\
\hline 30 & $\beta$-bourbonene & 1387 & 17.55 & 0.273 & 64 & Heneicosane & 2104 & 32.24 & 3.2075 \\
\hline 31 & Methyleugenol & 1407 & 18.43 & 1.3833 & 65 & Docosane & 2196 & 33.93 & 0.0545 \\
\hline 32 & $\begin{array}{l}\text { trans- } \\
\text { caryophyllene }\end{array}$ & 1422 & 18.53 & 1.0404 & 66 & Tricosane & 2296 & 35.59 & 0.488 \\
\hline 33 & $\alpha$-Guaiene & 1440 & 18.77 & 0.2303 & 67 & Tetracosane & 2400 & 36.67 & $\operatorname{tr}$ \\
\hline 34 & $\begin{array}{l}\text { Citronellyl } \\
\text { propionate }\end{array}$ & 1443 & 18.84 & 0.2203 & 68 & Pentacosane & 2440 & 37.3 & 0.0298 \\
\hline
\end{tabular}




\subsection{Geraniol}

Geraniol (3, 7-dimethylocta-trans-2, 6-dien-1-ol) is a compound that is extracted from the flowers of roses and many other plants $(44,45)$. Geraniol is a natural component of the plant's essential oils which has a rose-like odor and its taste is generally used as a flavoring in the food industry (44) (Figure 3). The U.S. Food and Drug Administration (FDA) approved it as a generally safe component (46). Geraniol, as a clear to pale-yellow oil, is poorly soluble in aqueous solutions whereas has a high solubility in common organic solvents (47). Geraniol presents several remarkable biochemical and pharmacological properties; it is an important plant-based insect repellent (48), it has antimicrobial, antioxidant, anti-inflammatory (49), and strong antibacterial activity (50), and is also an antifungal agent (51) (Figure 4). It shows anti-inflammatory effects on monocytes cell line (52). Geraniol exhibits in vitro and in vivo anti-tumor effects on murine leukemia, hematoma and melanoma cells $(53,54)$. Geraniol is a primary acyclic, unsaturated terpene alcohol with the chemical formula $\mathrm{C}_{10} \mathrm{H}_{18} \mathrm{O}_{4}$. It has a distinctive rose-like odor and the taste (at $10 \mathrm{ppm}$ ) is qualified as sweet floral rose-like, citrus with fruity and waxy c (49). Geraniol is found in oily tissues of several plants as well as frequently co-exists with its oxidation product like geranial and nerol (47). It is naturally found in many oils like Palmarosa, geranium or rose oils (55). It is also a lead molecule in the development of anticancer drugs $(46,56,57)$. Researchers have proven that GE is a useful plant for repelling insects (48). Also, several studies have specified the antimicrobial activity of this compound (51). In in vitro and in vivo studies, GE has been shown to inhibit the growth of murine leukemia, hepatoma and melanoma cells $(58,59)$.

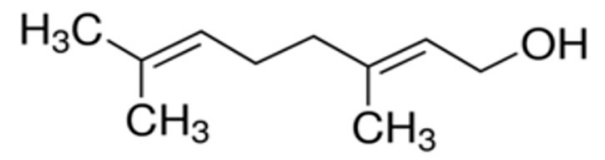

Figure 3. Chemical formula of geraniol

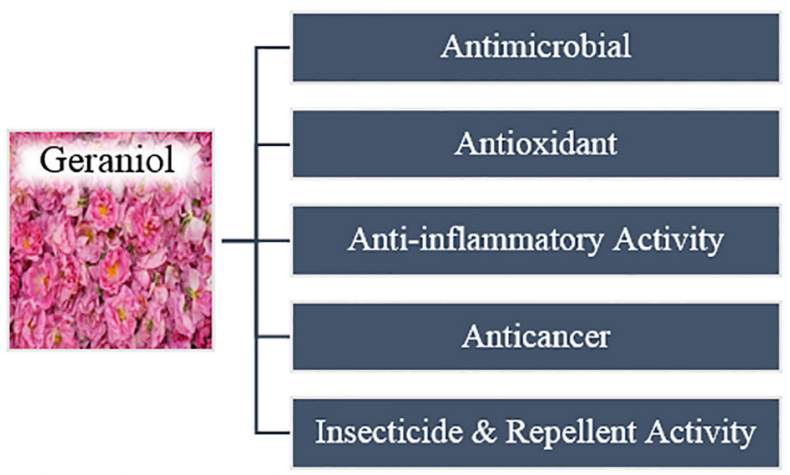

Figure 4. Health benefits of geraniol

\subsection{Functional properties of geraniol}

\subsubsection{Antimicrobial activity}

Essential oils show a strong inhibitory effect on many bacteria and fungi. When the essential oils are solved in the phospholipids bilayer of the cell membranes, its antimicrobial effect occurs (60). It was proved that some monoterpene alcohols such as citronellol, geraniol, Linalool and nerol, show more effective antibacterial properties than antifungal properties $(61,62)$. Gaseous GE presents an antibacterial effect on respiratory tract pathogens, such as $H$. Influenzae and S. Aureus. Friedman, Henika (63) compared essential oils ( $\mathrm{n}=96)$ and oil compounds (n=23) in terms of bactericidal activity levels against $C$. Jejuni, E. coli, L. monocytogenes and S. enterica from food and clinical sources. Geraniol showed higher activity against E. coli, L. Monocytogenes and S. enterica with a bactericidal activity value (BA50) of $0.15,0.28$ and 0.15 , respectively. Among 60 essential oils tested, GE was able to prevent human and animal pathogens, S. typhimurium and E. coli (64). Citronellol, GE and nerol presented minimum inhibitory concentrations (MICs) from 64 to $128 \mu \mathrm{g} \mathrm{ml}^{-1}$ against Mycobacterium tuberculosis (65). The GE obtained from M/s S H Kelkar, Mumbai was found to show stronger bacterial sensitivity to E. faecalis, $M$. smegmatis, $P$. aeruginosa, $S$. aureus and $S$. epidermidis over the sample obtained from another source. The GE exhibited $312.5 \mu \mathrm{g} \mathrm{mL}^{-1}$ MIC against E. coli, M. smegmatis, P. aeruginosa, S. typhi and Y. enterocolitica. However, $100 \mu \mathrm{g} \mathrm{mL} \mathrm{m}^{-1}$ strong activity from GE was found against $S$. mutans (66). Geraniol in an essential oil extracted from Palmarosa leads to the antifungal action against $S$. cerevisiae (67). Geraniol showed a strong antifungal effect on $C$. 
albicans. Palmarosa exhibits inhibitory activity against Cryptococcus neoformans, a fungus causing infection during

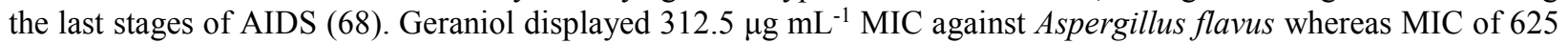
$\mu \mathrm{g} \mathrm{mL} \mathrm{m}^{-1}$ was obtained against Trichophyton rubrum and Microsporum gypseum (66). It has shown the main antifungal activities against Colletotrichum camelliae (MIC value $440 \mu \mathrm{g} \mathrm{mL}^{-1}$ ) (69). Geraniol $\left(25 \mu \mathrm{g} \mathrm{mL}^{-1}\right)$, in combination with vaginal washing, mainly inhibited the growth of viable $C$. albicans cells and improved vaginal inflammation (70).

\subsubsection{Antioxidant activity}

Free radicals cause molecular alteration related to Alzheimer's disease, aging, asthma, arteriosclerosis, cancer, and diabetes by oxidation of biomolecules (71). Experimental studies described several pharmacological activities of GE including anticancer and antioxidant activities (72). Mahmoud A. Saleh et al. evaluated the antioxidant activity of various essential oils and showed that the essential oils of the Rosaceae family were among the most effective compounds (73). The radical scavenging activity of $P$. graveolens essential oils was investigated using the 1,1diphenyl-2-pycrylhydrazyl (DPPH) method. The antioxidant activity values were obtained between $63.70 \mathrm{mg} \mathrm{mL}^{-1}$ for leaves to $64.88 \mathrm{mg} \mathrm{mL}^{-1}$ for stems (74). Recent studies showed that GE oil had antiradical activity (IC50 = 14.49 $\mathrm{mg} \mathrm{mL} \mathrm{m}^{-1}$ ) mainly stronger than acetone extract of the plant (IC50 $\left.=66.45 \mathrm{mg} \mathrm{mL}-1\right)(75)$. In a study on evaluating the antioxidant activity of Thymus daenensis (TD) containing $66.8 \%$ GE, $13.9 \%$ geranyl acetate, and $9.6 \% \beta$ caryophyllene, DPPH radical scavenging represented that TD essential oil extract had higher IC50 values than the antioxidant standards. Moreover, TD extract exhibited lower IC50 value $\left(194.24 \pm 0.021 \mu \mathrm{g} \mathrm{mL}^{-1}\right)$ than TD essential oil (76). In another study, the antioxidant activity of GE, geranyl acetate, gingerol and eugenol were evaluated. Lower IC50 value inferred higher antioxidant activity. Among these essential oils, GE, geranyl acetate, gingerol and eugenol exhibited 24.6, 4.2, 68.4 and $0.9 \mu \mathrm{g} \mathrm{mL}^{-1}$ IC50 values, respectively (77). The essential oils extracted from old leaves and flowers demonstrated the highest scavenging activity, which may be attributed to the presence of GE, nerol and some other terpenes in the Neroli oil $(78,79)$. The radical scavenging activity of 34 kinds of citrus essential oils and their volatile components was investigated by researchers (80). They used the DPPH method and compared the activity of essential oils with trolox as a standard antioxidant. Geraniol exhibited significant scavenging activity against the DPPH radical $\left(87.7 \%, 235.9 \mathrm{mg}\right.$ of trolox equiv $\left.\mathrm{ml}^{-1}\right)$. Antioxidant and anticancer effects of geranium oil are related to citronellol and trans-geraniol, the main components of it. Geraniol has a significant inhibitory potential to the growth of tumor cells of pancreas, as well (75). Antioxidant effect of GE in different in vitro models indicates the potential benefit of GE against oxidative stress (OS), a progressive pathological feature of neurodegenerative disorders (81).

\subsubsection{Anticancer activity}

Geraniol exerts protective effects and chemotherapeutic activity toward many human cancers such as pancreatic cancer (58). Geraniol exhibits a new class of chemopreventive cancer agents as it has inhibitory activity on CaCo2 colon cancer cells (57). Geraniol presents in vitro and in vivo antitumor activity against several cell lines. In fact, it changes several lipid metabolic pathways of $\mathrm{HepG} 2$ cells such as mevalonate pathway and the phosphatidylcholine biosynthesis, which leads to inhibited cell growth, and cell cycle impedance that is occurring at the G0/G1 interphase and enhanced apoptosis (82). Geraniol has significant (60-90\%) inhibition of the anchorage-independent growth of human MIAPACa2 pancreatic tumor cells (58). Crowel reported that dietary GE obstructed hepatic HMG CoA reductase activity and decreased the level of serum cholesterol in experimental animals (83). The interaction of GE with 3-hydroxy-3-methylglutaryl-CoA (HMG-CoA) reductase is reported (84). It has been found that GE can prevent proliferation, cell cycle progression and cyclin-dependent Kinase 2 activity in MCF-7 breast cancer cells with no effect on the activity of HMG-CoA reductase (85). A study revealed that GE inhibits prostate cancer growth and also enhances the sensitivity of the affected cells to chemotherapeutic agents (86). Manoharan and Selvan (87) found that oral administration of GE to 7,12 dimethylbenz(a) anthracene (DMBA) treated mice, prevented the formation of tumor in $83 \%$ of animals. Furthermore, GE significantly decreased the histological abnormalities in the skin tissues of DMBA daubed mice. They also presented that GE may have inhibited unnatural cell accumulation in skin tissues during DMBA induced skin carcinogenesis. They reported that oral administration of GE mainly enhanced the activities of phase II enzymes and the level of glutathione in DMBA daubed mice. These results present that GE provoke the activities of phase II detoxification cascade to ward off the active metabolite of DMBA, the dihydrodiol epoxide. The antitumor activity of GE is thus partially in relationship with an induction of phase II detoxification enzymes and their antioxidant enzymes. They also presented chemo-preventive ability of GE in DMBA-induced skin carcinogenesis. It can be concluded that this ability of GE could be attributed to properties including anti-lipid peroxidative, antioxidant and modulatory effect on carcinogen detoxification process during DMBA-induced skin carcinogenesis. 


\subsubsection{Insecticide and repellent activity}

Essential oils of a large number of plants have the ability to be repellent against various Hematophagous arthropods $(88,89)$. They also presented repellent, and/or antifeedant effects and insecticidal action against insects (48). Geraniol and eugenol are effective attractants and are able to trap Japanese beetles, Popillia japonica Newman (90). It was shown that mixing doses of citronella, lemon (citrus lemon), rose (Rosa damascene), lavender or basil essential oils with distilled water is very efficient in preventing indoor insect pests (91). Hierro, Valero (92) have investigated the activity of some monoterpenoid compounds against Anisakis simplex. The results showed the activity of GE, citronellol, citral, carvacrol and cuminaldehyde at $125.5 \mu \mathrm{g} \mathrm{mL}^{-1}$ concentration. Geraniol and a number of compounds were found as fumigants against Musca domestica and T. castaneum. Geraniol, carveol, carvacrol, linalool, menthol, terpineol, thymol, verbenol and some other compounds are ovicidal against M.domestica eggs (93). The acaricidal activities of GE from Pelargonium graveolens oil on Tyrophagus putrescentiae, and the storage food mite, and comparing its activity with benzyl benzoate has been surveyed. The results showed that GE was more effective than benzyl benzoate with the $50 \%$ lethal dose value being $1.95 \mu \mathrm{g} \mathrm{cm} 3$ and $1.27 \mu \mathrm{g} \mathrm{cm} 3$, respectively (94). Mosquito bites lead to allergic responses and transfer several diseases such as malaria, yellow fever and dengue $(95,96)$. It has been proved that GE is an effective mosquito repellent (97). Geraniol-based products are available in several countries as natural repellents. It was found that GE candles were more effective than linalool and citronella candles in protecting a person from bites of mosquitoes and sand flies (98). A study comparing three botanical natural repellents proved that the longest protection time of a person from bites of mosquitoes was attained when lemongrass extract was combined with $25 \%$ GE oil (99).

\subsubsection{Anti-inflammatory activity}

Inflammation is a normal protective response provoked by tissue injury or infections, and functions to conflict invaders in the body (100). There is some evidence that essential oils have anti-inflammatory activity (101). For instance, citral, GE, citronellol and carvone can prevent the formation of pro-inflammatory cytokines such as TNF- $\alpha$ (102). It is proven that GE and some essential oils inhibit the formation of leukotriene, as a mediator of inflammation. Hence, they are beneficial in the treatment of various inflammatory diseases, including asthma, chronic bronchitis and allergic rhinitis among others (103). The studies that performed the anti-allergic effects (allergic rhinitis or pollinosis) of flavored and non-flavored chewing gums displayed that gums fortified with peppermint oils such as geraniol, 1-menthol, citronellol and 1,8-cineole were more efficient in decreasing rhinitis symptoms in comparison with non-flavored gums and normal peppermint-flavored gums $(104,105)$.

\section{Conclusions}

Rosa damascena, the most important member of Rosacea species, is chiefly familiar for its perfuming. Rose water and essential oil are major products of this plant. This plant has several components such as flavonoids, terpenes, anthocyanin and glycosides with useful effects on human health. One of the major compounds of Rosa damascene Mill is geraniol. It is the most abundant monoterpene presented in many plants. It is one of the major compounds of Rosa damascene Mill and is widely used as a fragrance and flavor material in the food industry in order to treat infectious diseases or acting as a preservative. Geraniol presents several remarkable properties such as anti-cancer, antioxidant, antimicrobial, insect repellent and anti-inflammatory activities. Its antimicrobial effect on a large number of bacteria and fungi has been proven. Geraniol as a lipid-soluble (non-polar) component exhibited significant scavenging activity against the DPPH radical and displayed anticancer activity in both of the in vitro and in vivo states in some of the human cancer models. Geraniol is also recognized as a natural pest control agent with low toxicity, because of its insecticidal and repellent properties.

\section{Acknowledgments:}

This review paper was supported by the National Nutrition and Food Technology Research Institute, Shahid Beheshti University of Medical Sciences.

\section{Conflict of Interest:}

There is no conflict of interest to be declared.

\section{Authors' contributions:}

All authors contributed to this project and article equally. All authors read and approved the final manuscript. 


\section{References:}

1) Sakarkar, D. and V. Deshmukh, Ethnopharmacological review of traditional medicinal plants for anticancer activity. Int J Pharm Tech Res, 2011. 3(1): 298-308.

2) Tavakkol, A., S. Fellman, and F. Kianifard, Safety and efficacy of oral terbinafine in the treatment of onychomycosis: Analysis of the elderly subgroup in improving results in ONychomycosis-concomitant lamisil ${ }^{\circledR}$ and debridement (IRON-CLAD), an open-label, randomized trial. The American journal of geriatric pharmacotherapy, 2006. 4(1): 1-13. doi: 10.1016/j.amjopharm.2005.12.012 PMid: 16730616

3) Teranishi, R., R.G. Buttery, and H. Sugisawa, Bioactive volatile compounds from plants. 1993: ACS Publications. doi: 10.1021/bk-1993-0525

4) Hadian, Z., et al., Preparation and characterization of nanoparticle $\beta$-cyclodextrin: Geraniol inclusion complexes. Iranian journal of pharmaceutical research: IJPR, 2018. 17(1): 39.

5) Yasa, N., et al., Chemical composition and antioxidant activity of the extract and essential oil of Rosa damascena from Iran, population of Guilan. DARU, 2009. 17;3: 175-80

6) Loghmani-Khouzani, H., Essential oil composition of Rosa damascena Mill cultivated in central Iran. Scientia Iranica, 2007. 14(4).

7) DEHGHAN, K.A., et al., Antioxidative properties and toxicity of white rose extract. Iranian Journal of Toxicology. 2011. 5;1: 415-25

8) Bernhoft, A., et al., Bioactive compounds in plants-benefits and risks for man and animals. The Norwegian Academy of Science and Letters, Oslo, 2010.

9) da Silva, B.V., J.C. Barreira, and M.B.P. Oliveira, Natural phytochemicals and probiotics as bioactive ingredients for functional foods: Extraction, biochemistry and protected-delivery technologies. Trends in Food Science \& Technology, 2016. 50: 144-58. doi: 10.1016/j.tifs.2015.12.007

10) Van Wyk, B.-E. and M. Wink, Medicinal plants of the world: an illustrated scientific guide to important medicinal plants and their uses. 2004: Timber Press.

11) Boskabady, M.H., et al., Pharmacological effects of Rosa damascena. Iranian journal of basic medical sciences, 2011. 14(4): 295.

12) Nayebi, N., et al., A systematic review of the efficacy and safety of Rosa damascena Mill. with an overview on its phytopharmacological properties. Complementary therapies in medicine, 2017. 34: 129-40. doi: 10.1016/j.ctim.2017.08.014 PMid: 28917365

13) Akram, M., et al., Chemical constituents, experimental and clinical pharmacology of Rosa damascena: a literature review. Journal of Pharmacy and Pharmacology, 2019. doi: 10.1111/jphp.13185, PMid: 31709541

14) Verma, S.R., C.R. Padalia, and A. Chauhan, Chemical investigation of the volatile components of shadedried petals of damask rose (Rosa damascena Mill.). Archives of Biological Sciences, 2011. 63(4): 1111-5. doi: 10.2298/ABS1104111V

15) Torki, M., A. Akbari, and F.M. Haghi, Comparing the repellency of different plant essential oils against mosquito culex pipiens. Indian drugs. 2017. 54:2: 29-35

16) Shokrzadeh, M., E. Habibi, and M. Modanloo, Cytotoxic and genotoxic studies of essential oil from Rosa damascene Mill., Kashan, Iran. Medicinski Glasnik, 2017. 14(2).

17) Modanloo, M. and E. Habibi, Cytotoxic and genotoxic studies on essential oil from Rosa damascene Mill., Kashan, Iran. Med Glas (Zenica). 1;14(2):152-7. doi: 10.17392/901-17.

18) Esmaeili, S., et al., Antiplasmodial activity and cytotoxicity of plants used in traditional medicine of Iran for the treatment of fever. Iranian journal of pharmaceutical research: IJPR, 2015. 14(Suppl): 103.

19) Briskin, D.P., Medicinal plants and phytomedicines. Linking plant biochemistry and physiology to human health. Plant physiology, 2000. 124(2): 507-14. doi: 10.1104/pp.124.2.507, PMid: 11027701, PMCid: PMC1539282

20) Pan, L., H.-B. Chai, and A.D. Kinghorn, Discovery of new anticancer agents from higher plants. Frontiers in bioscience (Scholar edition), 2012. 4: 142. doi: 10.2741/s257

21) Lang, G. and G. Buchbauer, A review on recent research results (2008-2010) on essential oils as antimicrobials and antifungals. A review. Flavour and Fragrance Journal, 2012. 27(1): 13-39. doi: $10.1002 / \mathrm{ffj} .2082$

22) Kaul, V., S. Virendra, and S. Bikram, Damask rose and marigold: prospective industrial crops. Journal of Medicinal and Aromatic Plant Sciences, 2000. 22(1B): 313-8.

23) Loghmani-Khouzani, H., O. Sabzi Fini, and J. Safari, Essential oil composition of Rosa damascena Mill cultivated in central Iran. Scientia Iranica, 2007. 14(4): 316-9. 
24) Cai, Y.-Z., et al., Phenolic antioxidants (hydrolyzable tannins, flavonols, and anthocyanins) identified by LC-ESI-MS and MALDI-QIT-TOF MS from Rosa chinensis flowers. Journal of agricultural and food chemistry, 2005. 53(26): 9940-8. doi: 10.1021/jf052137k, PMid: 16366678

25) Gudin, S., Rose: genetics and breeding. Plant breeding reviews, 2000. 17: 159-90. doi: 10.1002/9780470650134.ch3

26) Romeilah, R.M., S.A. Fayed, and G.I. Mahmoud, Chemical compositions, antiviral and antioxidant activities of seven essential oils. Journal of Applied Sciences Research, 2010. 6(1): 50-62.

27) Chevallier, A., The Encyclopedia of Medicinal Plants, 1996. A DK Publishing Book, Boston. 33: 142.

28) Shalit, M., et al., Volatile ester formation in roses. Identification of an acetyl-coenzyme A. Geraniol/citronellol acetyltransferase in developing rose petals. Plant Physiology, 2003. 131(4): 1868-76. doi: 10.1104/pp.102.018572, PMid: 12692346, PMCid: PMC166943

29) Folta, K.M. and S.E. Gardiner, Genetics and genomics of Rosaceae. 2009: Springer. doi: 10.1007/978-0387-77491-6

30) Moein, M., et al., Composition of the Essential Oil of Rosa damascenea Mill. from South of Iran. Iranian Journal of Pharmaceutical Sciences, 2010. 6(1): 59-62.

31) Moein, M., H. Etemadfard, and M.M. Zarshenas, Investigation of different Damask rose (Rosa damascena Mill.) oil samples from traditional markets in Fars (Iran); focusing on the extraction method. Trends in Pharmaceutical Sciences, 2016. 2(1): 51-58.

32) Yassa, N., et al., Chemical composition and antioxidant activity of the extract and essential oil of Rosa damascena from Iran, population of Guilan. DARU Journal of Pharmaceutical Sciences, 2015. 17(3): 17580.

33) William, D., C. Warden, and D. Hooper, Pharmacographia Indica, A history of the principal drugs of vegetable origin. Vol-III. Srishti book distributors: New Delhi, 2005: 286-91.

34) Olgunsoy, P., S. Ulusoy, and U. ÇELIKKOL-AKÇAY, Metabolite Production and Antibacterial Activities of Callus Cultures from Rosa damascena Mill. Petals. Marmara Pharmaceutical Journal, 2017. 21(3): 5907. doi: 10.12991/marupj.319331

35) Kovats, E.S., Composition of essentialoils: part7. bulgarianoil of rose (rosadamascenamill). 1987.

36) Mahmood, N., et al., The Anti-HIV Activity and Mechanisms of Action of Pure Compounds Isolated fromRosa damascena. Biochemical and biophysical research communications, 1996. 229(1): 73-79. doi: 10.1006/bbrc.1996.1759, PMid: 8954085

37) Baydar, N.G. and H. Baydar, Phenolic compounds, antiradical activity and antioxidant capacity of oilbearing rose (Rosa damascena Mill.) extracts. Industrial Crops and Products, 2013. 41: 375-80. doi: 10.1016/j.indcrop.2012.04.045

38) Fatemeh, F., et al., Extraction of Rosa damascena as an antibacterial agent. International Journal of Mycobacteriology, 2015. 4: 169. doi: 10.1016/j.jimyco.2014.11.053

39) Shohayeb, M., et al., Antibacterial and antifungal activity of Rosa damascena MILL. essential oil, different extracts of rose petals. Global J. of Pharmacol, 2014. 8: 1-7.

40) Ody, P., The Herb Society's Complete Medicine Herbal. Dorling Kindersley, London, 1995.

41) Soliman, K. and R. Badeaa, Effect of oil extracted from some medicinal plants on different mycotoxigenic fungi. Food and chemical toxicology, 2002. 40(11): 1669-75. doi: 10.1016/S0278-6915(02)00120-5

42) Carson, C.F. and K.A. Hammer, Chemistry and bioactivity of essential oils. Lipids and Essential Oils as Antimicrobial Agents, 2011: 203-38. doi: 10.1002/9780470976623.ch9

43) Vuong, Q., et al., Fruit-derived phenolic compounds and pancreatic cancer: Perspectives from Australian native fruits. Journal of ethnopharmacology, 2014. 152(2): 227-42. doi: 10.1016/j.jep.2013.12.023, PMid: 24463158

44) Antonelli, A., et al., Characterization of 24 old garden roses from their volatile compositions. Journal of Agricultural and Food Chemistry, 1997. 45(11): 4435-9. doi: 10.1021/jf9702407

45) Rao, B.R., et al., Volatile flower oils of three genotypes of rose-scented geranium (Pelargonium sp.). Flavour and fragrance journal, 2000. 15(2): 105-7. doi: 10.1002/(SICI)10991026(200003/04)15:2<105::AID-FFJ875>3.0.CO;2-G

46) Lapczynski, A., et al., Fragrance material review on geraniol. Food and Chemical Toxicology, 2008. 46(11): S160-S170. doi: 10.1016/j.fct.2008.06.048, PMid: 18640215

47) Regev, S. and W.W. Cone, Analyses of Pharate Female Twospotted Spider Mites 1 for Nerolidol and Geraniol: Evaluation for Sex 2 Attraction of Males. Environmental Entomology, 1976. 5(1): 133-8. doi: 10.1093/ee/5.1.133 
48) Barnard, D.R. and R.-D. Xue, Laboratory evaluation of mosquito repellents against Aedes albopictus, Culex nigripalpus, and Ochlerotatus triseriatus (Diptera: Culicidae). Journal of medical entomology, 2004. 41(4): 726-30. doi: 10.1603/0022-2585-41.4.726, PMid: 15311467

49) Chen, W. and A. Viljoen, Geraniol-a review of a commercially important fragrance material. South African Journal of Botany, 2010. 76(4): 643-51. doi: 10.1016/j.sajb.2010.05.008

50) Andoğan, B.C., et al., Antimicrobial activity and chemical composition of some essential oils. Archives of pharmacal research, 2002. 25(6): 860-4. doi: 10.1007/BF02977005, PMid: 12510839

51) Bard, M., et al., Geraniol interferes with membrane functions in strains ofCandida andSaccharomyces. Lipids, 1988. 23(6): 534-8. doi: 10.1007/BF02535593, PMid: 3050345

52) Marcuzzi, A., S. Crovella, and A. Pontillo, Geraniol rescues inflammation in cellular and animal models of mevalonate kinase deficiency. In vivo, 2011. 25(1): 87-92.

53) Pan, Q., et al., Monoterpenoid indole alkaloids biosynthesis and its regulation in Catharanthus roseus: a literature review from genes to metabolites. Phytochemistry reviews, 2016. 15(2): 221-50. doi: 10.1007/s11101-015-9406-4

54) de Carvalho, K.I.M., et al., Geraniol-a flavoring agent with multifunctional effects in protecting the gastric and duodenal mucosa. Naunyn-Schmiedeberg's archives of pharmacology, 2014. 387(4): 355-65. doi: 10.1007/s00210-013-0947-z, PMid: 24337826

55) Croteau, R. and F. Karp, Origin of natural odorants, in Perfumes. 1994, Springer. 101-26. doi: 10.1007/978-94-011-3826-0_4

56) Kim, S.-H., et al., Geraniol inhibits prostate cancer growth by targeting cell cycle and apoptosis pathways. Biochemical and biophysical research communications, 2011. 407(1): 129-34. doi: 10.1016/j.bbrc.2011.02.124, PMid: 21371438

57) Carnesecchi, S., et al., Geraniol, a component of plant essential oils, sensitizes human colonic cancer cells to 5-fluorouracil treatment. Journal of Pharmacology and Experimental Therapeutics, 2002. 301(2): 625-30. doi: 10.1124/jpet.301.2.625, PMid: 11961066

58) Burke, Y.D., et al., Inhibition of pancreatic cancer growth by the dietary isoprenoids farnesol and geraniol. Lipids, 1997. 32(2): 151-6. doi: 10.1007/s11745-997-0019-y, PMid: 9075204

59) Suzanne, G.Y., L.A. Hildebrandt, and C.E. Elson, Geraniol, an inhibitor of mevalonate biosynthesis, suppresses the growth of hepatomas and melanomas transplanted to rats and mice. The Journal of nutrition, 1995. 125(11): 2763.

60) Dorman, H. and S. Deans, Antimicrobial agents from plants: antibacterial activity of plant volatile oils. Journal of applied microbiology, 2000. 88(2): 308-16. doi: 10.1046/j.1365-2672.2000.00969.x, PMid: 10736000

61) Suppakul, P., et al., Antimicrobial properties of basil and its possible application in food packaging. Journal of agricultural and food chemistry, 2003. 51(11): 3197-3207. doi: 10.1021/jf021038t, PMid: 12744643

62) Inouye, S., T. Takizawa, and H. Yamaguchi, Antibacterial activity of essential oils and their major constituents against respiratory tract pathogens by gaseous contact. Journal of antimicrobial chemotherapy, 2001. 47(5): 565-73. doi: 10.1093/jac/47.5.565, PMid: 11328766

63) Friedman, M., P.R. Henika, and R.E. Mandrell, Bactericidal activities of plant essential oils and some of their isolated constituents against Campylobacter jejuni, Escherichia coli, Listeria monocytogenes, and Salmonella enterica. Journal of food protection, 2002. 65(10): 1545-60. doi: 10.4315/0362-028X65.10.1545, PMid: 12380738

64) $\mathrm{Si}$, W., et al., Antimicrobial activity of essential oils and structurally related synthetic food additives towards selected pathogenic and beneficial gut bacteria. Journal of Applied Microbiology, 2006. 100(2): 296-305. doi: 10.1111/j.1365-2672.2005.02789.x, PMid: 16430506

65) Cantrell, C.L., S.G. Franzblau, and N.H. Fischer, Antimycobacterial plant terpenoids. Planta medica, 2001. 67(08): 685-94. doi: 10.1055/s-2001-18365, PMid: 11731906

66) Singh, D., et al., Antimicrobial activity of some promising plant oils, molecules and formulations. 2012.

67) Prashar, A., et al., Antimicrobial action of palmarosa oil (Cymbopogon martinii) on Saccharomyces cerevisiae. Phytochemistry, 2003. 63(5): 569-75. doi: 10.1016/S0031-9422(03)00226-7

68) Viollon, C. and J.-P. Chaumont, Antifungal properties of essential oils and their main components uponCryptococcus neoformans. Mycopathologia, 1994. 128(3): 151-3. doi: 10.1007/BF01138476, PMid: 7739729

69) Zhang, Z.-Z., et al., Antifungal activities of major tea leaf volatile constituents toward Colletorichum camelliae Massea. Journal of agricultural and food chemistry, 2006. 54(11): 3936-40. doi: 10.1021/jf060017m, PMid: 16719518 
70) Maruyama, N., et al., Protective activity of geranium oil and its component, geraniol, in combination with vaginal washing against vaginal candidiasis in mice. Biological and Pharmaceutical Bulletin, 2008. 31(8): 1501-6. doi: 10.1248/bpb.31.1501, PMid: 18670079

71) Edris, A.E., Pharmaceutical and therapeutic potentials of essential oils and their individual volatile constituents: a review. Phytotherapy research, 2007. 21(4): 308-23. doi: 10.1002/ptr.2072, PMid: 17199238

72) Tiwari, M. and P. Kakkar, Plant derived antioxidants-geraniol and camphene protect rat alveolar macrophages against t-BHP induced oxidative stress. Toxicology in vitro, 2009. 23(2): 295-301. doi: 10.1016/j.tiv.2008.12.014, PMid: 19135518

73) Saleh, M.A., et al., Antioxidant and free radical scavenging activities of essential oils. Ethnicity \& disease, 2010. 20(1): 78.

74) Ćavar, S. and M. Maksimović, Antioxidant activity of essential oil and aqueous extract of Pelargonium graveolens L'Her. Food Control, 2012. 23(1): 263-7. doi: 10.1016/j.foodcont.2011.07.031

75) Fayed, S.A., Antioxidant and anticancer activities of Citrus reticulate (Petitgrain Mandarin) and Pelargonium graveolens (Geranium) essential oils. Research Journal of Agriculture and Biological Sciences, 2009. 5(5): 740-7.

76) Sabahi, Z., et al., Essential oil composition and in vitro antioxidant activity of ethanolic extract of Thymus daenensis Celak from Iran. Global J Pharmacol, 2013. 7: 153-8.

77) Farhath, M.S., P. Vijaya, and M. Vimal, Antioxidant activity of geraniol, geranial acetate, gingerol and eugenol. Research in Pharmacy, 2015. 3(1).

78) Sarrou, E., et al., Volatile constituents and antioxidant activity of peel, flowers and leaf oils of Citrus aurantium L. growing in Greece. Molecules, 2013. 18(9): 10639-47. doi: 10.3390/molecules180910639, PMid: 24002139, PMCid: PMC627048

79) SONG, H.-S., H. UKEDA, and M. SAWAMURA, Antioxidative activities of citrus peel essential oils and their components against linoleic acid oxidation. Food Science and Technology Research, 2001. 7(1): 50-6. doi: $10.3136 /$ fstr.7.50

80) Choi, H.-S., et al., Radical-scavenging activities of citrus essential oils and their components: detection using 1, 1-diphenyl-2-picrylhydrazyl. Journal of agricultural and food chemistry, 2000. 48(9): 4156-61. doi: 10.1021/jf000227d, PMid: 10995330

81) Prasad, S.N. and M. Muralidhara, Analysis of the antioxidant activity of geraniol employing various invitro models: Relevance to neurodegeneration in diabetic neuropathy. Asian Journal of Pharmaceutical and Clinical Research, 2017. 10(7): 101-5. doi: 10.22159/ajpcr.2017.v10i7.18564

82) Crespo, R., et al., Transcriptional and posttranscriptional inhibition of HMGCR and PC biosynthesis by geraniol in 2 Hep-G2 cell proliferation linked pathways. Biochemistry and Cell Biology, 2012. 91(3): 1319. doi: 10.1139/bcb-2012-0076, PMid: 23668785

83) Crowell, P.L., Prevention and therapy of cancer by dietary monoterpenes. The Journal of nutrition, 1999. 129(3): 775S-778S. doi: 10.1093/jn/129.3.775S, PMid: 10082788

84) Pattanayak, M., et al., Geraniol and limonene interaction with 3-hydroxy-3-methylglutaryl-CoA (HMG$\mathrm{CoA}$ ) reductase for their role as cancer chemo-preventive agents. J Proteomics Bioinform, 2009. 2: 466-74. doi: $10.4172 /$ jpb. 1000107

85) Duncan, R.E., et al., Geraniol and $\beta$-ionone inhibit proliferation, cell cycle progression, and cyclindependent kinase 2 activity in MCF-7 breast cancer cells independent of effects on HMG-CoA reductase activity. Biochemical pharmacology, 2004. 68(9): 1739-47. doi: 10.1016/j.bcp.2004.06.022, PMid: 15450939

86) Vinothkumar, V., et al., Geraniol protects cell surface glycoconjugates abnormalities during 7, 12dimethylbenz (a) anthracene induced oral carcinogenesis. Journal of Cell and Tissue Research, 2011. 11(2): 2759.

87) Manoharan, S. and M.V. Selvan, Chemopreventive potential of geraniol in 7, 12-dimethylbenz (a) anthracene (DMBA) induced skin carcinogenesis in Swiss albino mice. Journal of Environmental Biology, 2012. 33(2): 255.

88) Velu, K., et al., Evaluation of silver nanoparticles toxicity of Arachis hypogaea peel extracts and its larvicidal activity against malaria and dengue vectors. Environmental Science and Pollution Research, 2015. 22(22): 17769-79. doi: 10.1007/s11356-015-4919-3, PMid: 26154036

89) Adorjan, B. and G. Buchbauer, Biological properties of essential oils: an updated review. Flavour and Fragrance Journal, 2010. 25(6): 407-26. doi: 10.1002/ffj.2024 
90) Vargas, R.I., et al., Methyl eugenol and cue-lure traps for suppression of male oriental fruit flies and melon flies (Diptera: Tephritidae) in Hawaii: effects of lure mixtures and weathering. Journal of Economic Entomology, 2000. 93(1): 81-7. doi: 10.1603/0022-0493-93.1.81, PMid: 14658515

91) Zaridah, M., et al., Larvicidal properties of citronellal and Cymbopogon nardus essential oils from two different localities. Trop Biomed, 2003. 20(2): 169-74.

92) Hierro, I., et al., Action of different monoterpenic compounds against Anisakis simplex sl L3 larvae. Phytomedicine, 2004. 11(1): 77-82. doi: 10.1078/0944-7113-00375, PMid: 14971725

93) Rice, P.J. and J.R. Coats, Insecticidal properties of several monoterpenoids to the house fly (Diptera: Muscidae), red flour beetle (Coleoptera: Tenebrionidae), and southern corn rootworm (Coleoptera: Chrysomelidae). Journal of Economic Entomology, 1994. 87(5): 1172-9. doi: 10.1093/jee/87.5.1172, PMid: 7962947

94) Jeon, J., C. Lee, and H. Lee, Food protective effect of geraniol and its congeners against stored food mites. Journal of food protection, 2009. 72(7): 1468-71. doi: 10.4315/0362-028X-72.7.1468, PMid: 19681271

95) Katz, T.M., J.H. Miller, and A.A. Hebert, Insect repellents: historical perspectives and new developments. Journal of the American Academy of Dermatology, 2008. 58(5): 865-71. doi: 10.1016/j.jaad.2007.10.005, PMid: 18272250

96) Karunamoorthi, K., A. Mulelam, and F. Wassie, Assessment of knowledge and usage custom of traditional insect/mosquito repellent plants in Addis Zemen Town, South Gonder, North Western Ethiopia. Journal of ethnopharmacology, 2009. 121(1): 49-53. doi: 10.1016/j.jep.2008.09.027, PMid: 18977426

97) Omolo, M.O., et al., Repellency of essential oils of some Kenyan plants against Anopheles gambiae. Phytochemistry, 2004. 65(20): 2797-802. doi: 10.1016/j.phytochem.2004.08.035, PMid: 15474566

98) Müller, G.C., et al., Indoor protection against mosquito and sand fly bites: a comparison between citronella, linalool, and geraniol candles. Journal of the American Mosquito Control Association, 2008. 24(1): 150-3. doi: 10.2987/8756-971X(2008)24[150:IPAMAS]2.0.CO;2

99) Qualls, W.A. and R.-D. Xue, Field evaluation of three botanical repellents against Psorophora ferox, Aedes atlanticus, and Aedes mitchellae. Journal of the American Mosquito Control Association, 2009. 25(3): 37981. doi: 10.2987/09-5850.1, PMid: 19852232

100) Stevenson, D. and R. Hurst, Polyphenolic phytochemicals-just antioxidants or much more? Cellular and Molecular Life Sciences, 2007. 64(22): 2900-16. doi: 10.1007/s00018-007-7237-1, PMid: 17726576

101) Kamatou, G.P. and A.M. Viljoen, A review of the application and pharmacological properties of $\alpha$-bisabolol and $\alpha$-bisabolol-rich oils. Journal of the American Oil Chemists' Society, 2010. 87(1): 1-7. doi: 10.1007/s11746-009-1483-3

102) Abe, S., et al., Suppression of tumor necrosis factor-alpha-induced neutrophil adherence responses by essential oils. Mediators of inflammation, 2003. 12(6): 323-8. doi: 10.1080/09629350310001633342, PMid: 14668091, PMCid: PMC1781633

103) Ahn, G., et al., Essential oil component having inhibition activity of leukotriene production. Korea Patent, 2001. 2102837321: 12.

104) Arakawa, T. and K. Osawa, Pharmacological study and application to food of mint flavourantibacterial and antiallergic principles. Aroma Research, 2000. 1(1): 20-3.

105) ARAKAWA, T., et al., Anti-allergic effects of peppermint oil, chicle and jelutong. Food Hygiene and Safety Science (Shokuhin Eiseigaku Zasshi), 1992. 33(6): 569-575_1. doi: 10.3358/shokueishi.33.569 